\section{REFERENCES}

Adams, L.W. \& Dove, L.E. (1984). Urban Wetlands for Stormwater Control and Wildlife Enhancement. National Institute for Urban Wildlife, Columbia, Maryland, USA: 15 pp., illustr.

ADams, L.W. \& Dove, L.E. (1989). Wildlife Reserves and Corridors in the Urban Environment: A Guide to Ecological Landscape Planning and Resource Conservation. National Institute for Urban Wildlife, Columbia, Maryland, USA: vi + 91 pp.. illustr.

Adams, L.W. \& Leedy, D.L. (Eds) (1987). Integrating Man and Nature in the Metropolitan Environinent. National Institute for Urban Wildlife, Columbia, Maryland, USA: viii +249 pp., illustr.

LeEdy, D.L. (1979). An Annotated Bibliography on Planning and Management for Urban-Suburban Wildlife. FWS/OBS79/25, US Fish and Wildlife Service, Washington, DC. USA: $256 \mathrm{pp}$.
LEEDY, D.L. \& ADAMS, L.W. (1984). A Guide to Urban Wildlifo Management. National Institute for Urban Wildlife, Columbia, Maryland, USA: ii + 42 pp., illustr.

Leedy, D.L., Maestro, R.M. \& Franklin, T.M. (1978). Planning for Wildlife in Cities and Suburbs. FWS/OBS-77/66. US Fish and Wildlife Service, Washington, DC, USA: vii + 64 pp.. illustr.

Leedy, D.L., Franklin, T.M. \& Maestro, R.M. (1981). Planning for Urban Fishing and Waterfront Recreation. FWS/OBS80/35, US Fish and Wildlife Service, Washington, DC. USA: viii +108 pp., illustr.

LOWELl W. ADAMS, Vice-President for Research National Institute for Urban Wildlife 10921 Trotting Ridge Way

Columbia

Maryland 21044

USA.

\title{
International Association for Impact Assessment
}

The International Association for Impact Assessment (IAIA) is an organization of research workers and other professionals, as well practitioners and users of impact assessment. It was formed in 1981 and has since grown to comprise a membership of 575 people in 45 countries. Each year the Association convenes a conference or smaller meeting to share the experiences of its members concerning the impact of plans, projects, programmes, and other developments, occurring throughout the world. In some instances IAIA Chapters will hold meetings, and several regional meetings have occurred. Regional Chapters exist, or are being organized, in Australia, New Zealand, the Caribbean, Western Europe, and North America.

The main goal of IAIA is to advance the state of the art of impact assessment and to foster its application to impact situations and conditions at scales ranging from local all the way to global ${ }^{*}$. Forms of impact assessment include: technology assessment, environmental impact assessment, social impact assessment, and risk assessment. Equally, we encourage the development of international and local capability to anticipate, plan, and manage, the conse-

\footnotetext{
* and in due course, doubtless, Universal.-Ed.
}

quences of impacts, so as to enhance the quality of life for all.

IAIA provides a non-political forum to exchange ideas and experiences. It aims to stimulate innovation in dealing with the consequences of development. Opportunities for IAIA participation include research networks around specialized assessment topics of interest to members-such as robotics, social forecasting, and international impacts.

Members of the IAIA receive the Impact Assessment Bulletin, a quarterly of short articles and reviews, and a newsletter on current events and IAIA activities. The 1990 IAIA Annual Conference is scheduled for Beijing, China, and will concentrate on the theme: Development and Environment. Dues are: Individual Members, $\$ 30$ US; Joint Members, $\$ 40$ US; Student or Retired, \$15 US; and Institution, $\$ 60$ US. Further details can be obtained from the undersigned:

\section{David HaRdy, Secretary}

The International Association for Impact Assessment c/o Industrial and Systems Engineering Georgia Institute of Technology

Atlanta

Georgia 30332, USA.

\section{Aims and Activities of Sol 3}

Sol 3 was founded in 1986 with the specific aim of bringing together mature individuals from all over the world with a common interest, so that they might study together and exchange ideas. Although originally conceived as a study-group for those interested in mathematics and the physical sciences, our group has more recently, and at the request of members, become concerned with ecological and humanitarian issues.

We are not an organization as such, but rather an informal affiliation of aware individuals. Members are welcome to use our facilities at any time, to exchange ideas, or to follow some formal course of study or research. The group is funded by donations from members, but no member is under any obligation to contribute to any specific project.

In February 1989, our First International Assembly on Deforestation was held in our village in Valais, Switzerland, with representatives from groups based in Geneva, but working on projects as far apart as Brazil, Haiti, and various parts of Africa. April 1989 saw the Second International Assembly on Deforestation take place in Geneva, with almost 50 organizations represented, and from almost all parts of the world.

Since then, we have sponsored a representative to the Enquete-Kommission in Bonn, and produced a report, which is currently being circulated, on the annual destruction wreaked by burning and other means in the Brazilian Amazon. One of our members is attending the Planetterre conference in Paris.

During 19-20 June 1989 we held a Round Table, as a follow-up to the April Assembly, at which a number of experts from the fields of law, economics, and sociology, met and discussed with environmentalists the causes of environmental destruction, and suggested possible courses of action. But why Sol 3 ? It is very simple-not an acronym - but count outwards from the Sun and the 3 represents a planet of special importance to us all.

CARL M. Haigh

Sol 3

3961 Vissoie

Valais

Switzerland. 